\title{
ECOLOGICAL IMPACT ASSESSMENT OF ROAD NETWORKS AT LANDSCAPE SCALE USING SPATIAL ROAD DISTURBANCE INDEX (SPROADI)
}

\author{
Shekoufeh NEMATOLLAHI, Sima FAKHERAN, Alireza SOFFIANIAN \\ Department of Natural Resources, Isfahan University of Technology, \\ Isfahan, 84156-83111, Iran
}

Submitted 23 Mar. 2016; accepted 27 Oct. 2016

\begin{abstract}
Development of roads can have deleterious effects on natural habitats containing species of conservation concern. Fragmentation of habitat into small, non-contiguous patches may result in dramatic population declinesThus appropriate studies quantifying ecological impacts of roads at landscape scale are essential. The main goal of this study was ecological impact assessment of roads network in Eastern part of Isfahan Province, including Abassabad wildlife refuge and Siahkouh National park, which are among the most important habitats for Asiatic Cheetah (Acinonyx jubatus venaticus) classified as Critically Endangered (CR) on the IUCN Red List. For this purpose, Spatial Road Disturbance Index (SPROADI), as a new landscape index was applied for the ecological impact assessment of the roads. This index uses three sub-indices including traffic intensity, vicinity impact and fragmentation grade to calculate the ecological impacts of road networks. Results obtained through quantifying the landscape Index (SPROADI) showed that the degree of disturbance by roads network is between 0 and 54.53. Our results also revealed that 12 percent of Abassabad wildlife and wide range of suitable habitats for Asiatic Cheetah were affected by roads, which presents a conservation concern for this critically endangered species.
\end{abstract}

Keywords: ecological impact assessment, landscape index, SPROADI, conservation, habitat fragmentation, roads.

\section{Introduction}

Roads are an integral part of the transportation infrastructures, which deliver a wide range of social and economic benefits such as providing connectivity for people and enabling communities to rapidly expand into previously remote or inaccessible areas (Freudenberger et al. 2013). However, there is also growing evidence of the negative impacts of roads on adjacent habitats, wildlife populations and ecosystems, indicating that these infrastructures are a driving factor of biodiversity loss (Forman et al. 2003; Benítez-López et al. 2010; Eigenbrod et al. 2009; Lin 2015).

The effects of roads on biodiversity are cumulative, time-lagged, complex and often irreversible (Selva et al. 2011). Roads cause mortality due to collision with vehicles (van Langevelde et al. 2009; Trombulak, Frissell 2000; Forman et al. 2003), alternation in behavior (Laurance, Stouffer 2004; Parris, Schneider 2009; Hoskin, Goosem 2010), habitat loss (Rico et al. 2007; Ewers, Didham 2007), reduction of habitat quality for wildlife by increasing distance between remaining habitat patches (Goodwin, Fahrig 2002), isolation of populations, decreasing the overall landscape connectivity and restriction of gene flow (Keller et al. 2004; Epps et al. 2005; Riley et al. 2006; Balkenhol, Waits 2009) and reducing the resilience of populations and ecosystems to climate change (Jump, Peñuelas 2005).

To better understand how roads impact on wildlife populations and their habitats at landscape scale, it is necessary to quantify to which extent and degree they are affected by these infrastructures. So far, most of the methods and indices developed to quantify the influence of roads focused on quantifying physical impacts of roads by calculating the degree of habitat fragmentation including landscape cohesion index (Opdam et al. 2003), splitting density, splitting index, mesh size (Jaeger 2000) and landscape connectivity indices (Pascual-Hortal, Saura 2006).

The SpreAD-GIS was used to estimate the emission of sound pollution (Madadi et al. 2014), the Habitat Evaluation Procedure (HEP) was used to assess the ecological impacts of roads (Makki et al. 2013) and the Ecological Footprint indicators used into assess the environmental impact of road access to tourist activities (Martín-Cejas 2015). However, most of the study consider on roads.

But to have a more comprehensive assessment of roads effects, other parameters associated with disturbances of road networks should also be taken into account.

Corresponding author: Sima Fakheran

E-mail: fakheran@cc.iut.ac.ir 
Spatial Road Disturbance Index (SPROADI) as recently developed index by Freudenberger et al. (2013) to consider cumulative impacts of road networks on natural habitat. This index uses three sub-indices including traffic intensity, vicinity impact and fragmentation grade to calculate the cumulative effects of roads on biodiversity. Traffic intensity is a measure of traffic volume per time and space; vicinity impact is the measure of edge effect of roads on adjacent habitats; and fragmentation grade, indicating the degree to which the landscape is intersected by roads (Freudenberger et al. 2013). By applying this index, this would be possible to incorporate and assess the impacts of factors related to traffic density and distribution besides physical impacts of roads on biodiversity.

The main goals of this study were assessment of the ecological impacts of road networks on important habitats such as Abassabad wildlife refuge and Siahkouh national park located in the eastern part of Isfahan province using of SPROAD index. These habitats are among the most important habitats for some species of conservation concern such as Caracal (Caracal caracal), houbarabustard (chlamydotis undulate), sand cat (Felis margarita) and Asiatic cheetah (Acynonix jubaticus venaticus). Nowadays, the most important risk element for Asiatic Cheetah is road networks located in the study area. For example, the Ardakan-Choopanan as a main road, cross the Abassabad wildlife refuge. In recent years, lots of accidents were happened in this road, which showed the importance of this road to biodiversity loss (personal communication with wildlife guards of Abassabad wild life refuge and local people).

\section{Materials and methods}

\subsection{Study area}

Our study area, Naein and Khoor-o-Biabanak Counties is located at a distance of 145 kilometres away from east part of Isfahan province in Iran, with an approximate area of $38000 \mathrm{Km}^{2}$. The elevation in this region ranges from $700 \mathrm{~m}$ to $2451 \mathrm{~m}$ above the sea level with the average annual rainfall between 100-110 mm (Akbari et al. 2011). The dominant climate in study area includes hot and dry climate and also some moderate climate mostly found in south-western areas where the mountain ranges are found. Existence of different topographic features including rocky mountain ranges, deserts and sandy areas has provided suitable habitat conditions for a high variety of plant and animal species in this region (Akbari et al. 2011). In the study area, the density of road networks is low, though there is a main concern about this network where roads have been passed through some conservation sites in the county including Abassabad wildlife refuge (category IV IUCN) and Siahkouh national park (category II IUCN) and its effects on wildlife habitats. Abassabad is at southeastern part of study area, with an area of 3000 ha (Fig. 1). This wildlife refuge is among the most important protected areas with high diversity of plant (400 species) and animal species (about 100 species). Some species of high conservation value have been found in this wildlife refuge including Iranian ground jay (podoces pleskei) an endemic species of Iran, sand cat (Felis margarita), Leopard (panther pardus), Caracal (Caracal caracal) houbarabustard

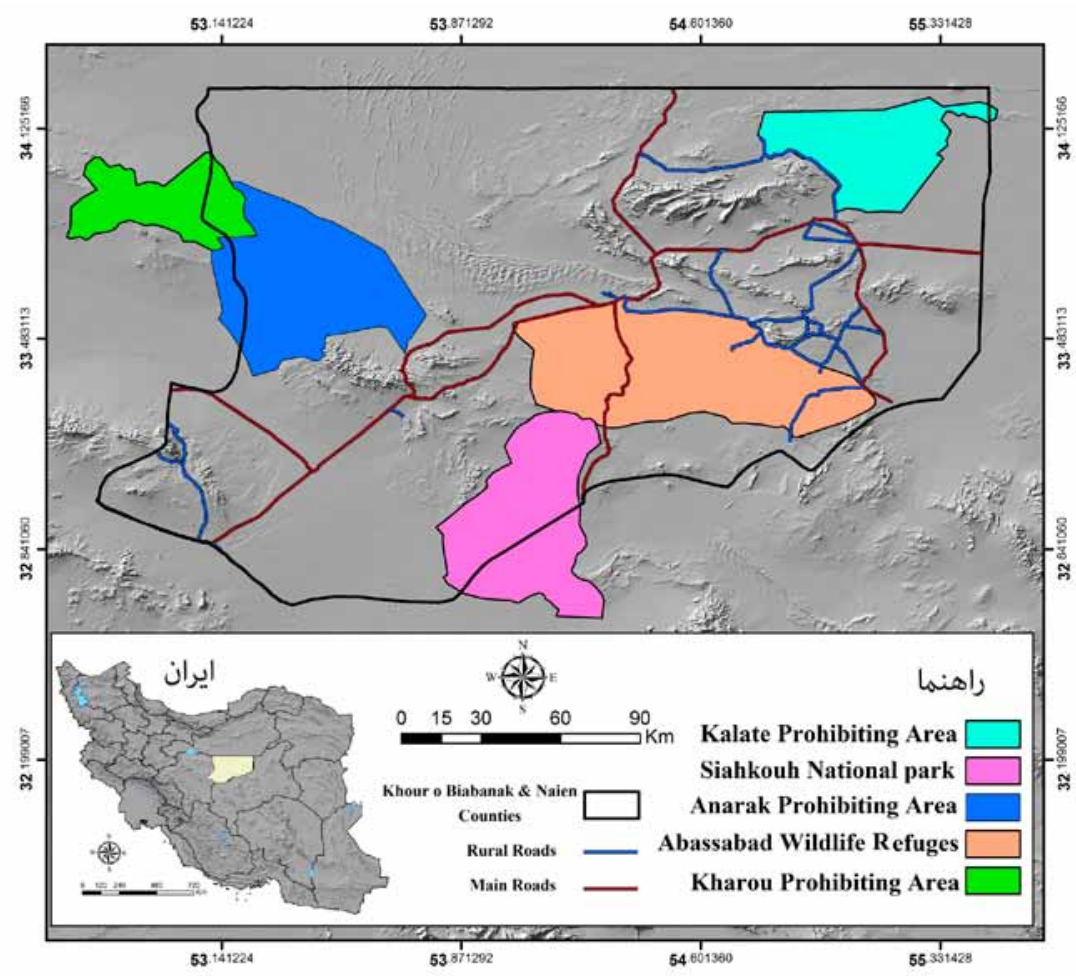

Fig. 1. Location of Study area and roads and protected areas 
(chlamydotis undulate), Jebeer gazelle (Gazella bennettii) and Wild goat (Capra aeagagrus). Siahkouh national park covers an area of 80000 ha and is located at south-west of the study area (Fig. 1) (Akbari et al. 2011). Both of these protected areas are well known as important stronghold across Isfahan for a critically endangered member of felidea family with a global distribution range limited only to Iran, Asiatic cheetah (Acynonix jubaticus venaticus). This species especially populations that live in Abassabad wildlife refuge have been seriously affected by these roads through collision with vehicles as a major factor resulted in high rate of the species mortality and destruction of suitable habitats for the species. These roads are also considered as barriers to movement between suitable habitats (Madadi et al. 2014).

\subsection{Input data}

The main input layers required for this study included the road networks and the traffic data maps of the study area. The road networks layer was prepared using topographic map with the scale of $1 / 250000$, Google earth, and converting the final layer to raster format. We excluded the urban area of Naein (some fraction of southwest part) from the study area, because of high density of roads which could bias the results of our study. Figure 1 shows the road networks and the location of protected areas in Eastern part of Isfahan province. As Figure 1 shows, the road density is high around Abassabad wild life refuge and Kalate prohibiting area and can have adverse effects on these protected areas.

\subsection{Spatial road disturbance Index development}

To calculate the SPROAD index including traffic intensity, vicinity impact and fragmentation grade, traffic data layer with appropriate resolution $\left(1 \mathrm{~km}^{2}\right.$ ) (Makki et al. 2013; Eigenbrod et al. 2009; Forman et al. 2003; UNEP 2001) was used as the basic map for producing three sub-indices. To produce the traffic intensity, vicinity impact and fragmentation grade layers, we used the formula developed by Freudenberger et al. (2013) as follow: Traffic intensity (T) is expressed as the average number of vehicles per hour (TV) (Table 1) multiplied by road length (R), and summed up for all road sections in a given cell as follow:

$$
T_{k}=\sum_{i=1}^{n_{k}} R_{k, i} \cdot T V_{k, i} .
$$

To achieve the number of vehicle per hour, we used the data from institution of roads transportation (Freudenberger et al. 2013) and then, to ensure the accuracy of our calculations, we checked our results with the data gained from Google earth time series in each road section in the study area (Madadi et al. 2014).

The vicinity impact (V) for a given cell represents the cumulative effect of all relevant roads as a function of their distance and traffic load. The vicinity impact can be calculated using the attributes of the neighbouring cells (Eq. (2)). In this study, 8 neighbour cells were used to calculate the vicinity impact (Freudenberger et al. 2013).

$$
V_{k}=\frac{1}{n_{k}} \cdot \sum_{v=1}^{n_{k}} T_{k, v},
$$

where $V_{K}$ is the vicinity impact on grid $k ; T_{k, v}$, traffic intensity in an adjacent $(v)$ grid cell $k ; v=\{1,2,3, \ldots$, $\left.n_{k}\right\}$, index variable for surrounding cells; $n_{k}$, number of surrounding cells of grid cell $k$. (Freudenberger et al. 2013). The effects of adjacent grid cells can be calculated by mentioned index. It means that the adjacent grid cell which roads passed through it can have adverse effects on the grid cell without any roads. To calculate Fragmentation grade, Eq. (3) was used (Freudenberger et al. 2013):

$$
F_{k}=\frac{A_{k}}{\sum_{j=1}^{n_{k}} A_{j, k} \cdot A_{j, k}^{c o m p l}},
$$

$F_{k}$, fragmentation grade of a grid cell $k ; j=\{1,2,3, \ldots$, $\left.n_{k}\right\}$, index variable for number of polygons; $n_{k}$, number of polygons without roads belonging to a grid cell $k ; A_{k}$, area size of a grid cell $k\left(\mathrm{~m}^{2}\right) ; A_{j, k}$, area size of the fraction of a polygon $j$ lying within a grid cell $k\left(\mathrm{~m}^{2}\right) ; A_{j, k}^{\text {compl }}$, area size of the complete polygon $j$ that $A_{j, k}$ is part of $\left(\mathrm{m}^{2}\right) ; A^{\text {compl }}$ total; total area size of all complete polygons intersecting a grid cell $k\left(\mathrm{~m}^{2}\right)$ (Freudenberger et al. 2013).

Because of different range of scales, all three subindices were normalized with the Fuzzy membership function in the GIS environment, using a scale ranged between 0 and 100 . Then, they were combined to generate the cumulative effects of road networks of the study area as SPROADI using Eq. (4). All sub-indices were weighted equally ( $w=0.33)$ (Freudenberger et al. 2013):

$$
\begin{aligned}
& \text { SPROADI } k=\sum_{i}^{n} w_{i} \cdot I_{k, \text { norm }}= \\
& w_{T} \cdot T_{k, \text { norm }}+w_{v} \cdot V_{k, \text { norm }}+w_{F} \cdot F_{k, \text { norm }} .
\end{aligned}
$$

$S P R O A D I_{k}=$ spatial road disturbance index of a grid cell $k ; n=$ number of sub-indices (in this case: 3 ); $w_{i}=\left\{w_{T}\right.$, $\left.w_{V}, w_{F}\right\}$ where $w$ stands for the assigned weight for each of the sub-indices. In this study we assigned equal weights to each, i.e. $w_{i}=0.33$, so that $\sum w_{i}=1$ and $0 \leq w_{i} \leq 1$ (Freudenberger et al. 2013).

In the second step of our study, we used the developed index for conservation planning target for the Asiatic cheetah. For this purpose, we used maps of the protected area network in the study area and the distribution model of the species along with the SPROAD index map to conduct a gap analysis and identifying less impacted unprotected habitats for the Asiatic cheetah in the study area for spatial prioritization of conservation areas. 


\section{Results and discussion}

The total length of road networks across Naien and Khooro-Biabanak Counties was approximately $1051 \mathrm{~km}$. Table 1, shows the average number of vehicles per hours calculated for the main roads included in our study area.

Based on the field observation and discussion with the head of Environmental Protection Agency, more than 30 accidents per year (with species such as caracal, wild cat, and houbara and Asiatic cheetah) were happened in the Naien-Anarak, Ardakan-Choopanan and AnarakChoopanan roads.

Table 1. The average number of vehicles per hours in the main roads

\begin{tabular}{lc}
\hline \multicolumn{1}{c}{ The name of road section } & Number of vehicles per hour \\
\hline Jandagh- Damghan & 174 \\
\hline Anarak- Khoor- 1 & 156 \\
\hline Naien- Anarak & 135 \\
\hline Ardakan- Choopanan & 102 \\
\hline Bayaze- Khoor & 50 \\
\hline Anarak- Khoor-46 & 39 \\
\hline
\end{tabular}

Raster maps of all three calculated sub-indices and the final map of SPROADI are shown in Figure 2. Comparison of the patterns of values among maps of sub-indices, in terms of having significant correlation revealed that there is a positive spatial correlation between values obtained for vicinity impact and traffic intensity. There is high traffic intensity in the central and southern part of the study area, where the Anarak-khoor and ArdakanChoopanan main roads with high traffic volume are located. The vicinity impact which reflects the impact of adjacent grid is high in the western and northern parts of the study area and the degree of habitat fragmentation is very high in the eastern part of the study area because of high road density in these parts.

Values for SPROADI map ranged from 0 to 54.53. High levels of road disturbances were obtained for areas at the vicinity of the Ardakan-Choopanan main road stretched from north to south of the Abassabad wild life refuge, and areas around the main road at south-western part of the study area. For these parts of the study area, high levels of traffic intensity and vicinity impact were recorded. However, low levels of road disturbances were obtained for areas around the rural road at the eastern part of the study area.
1)

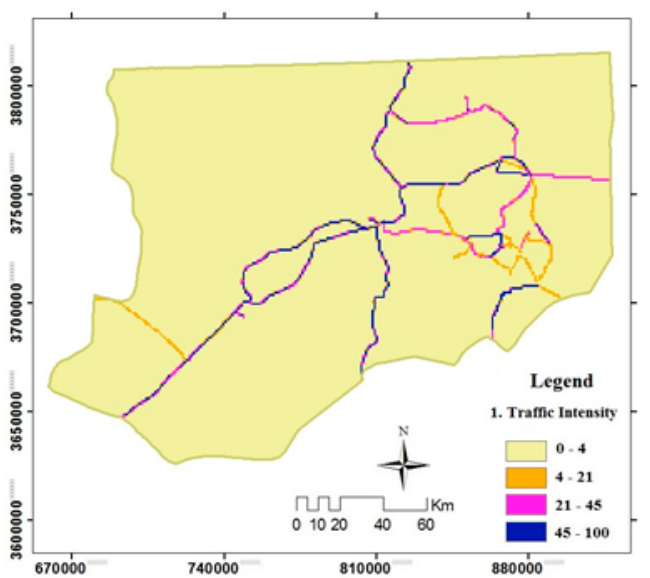

3)

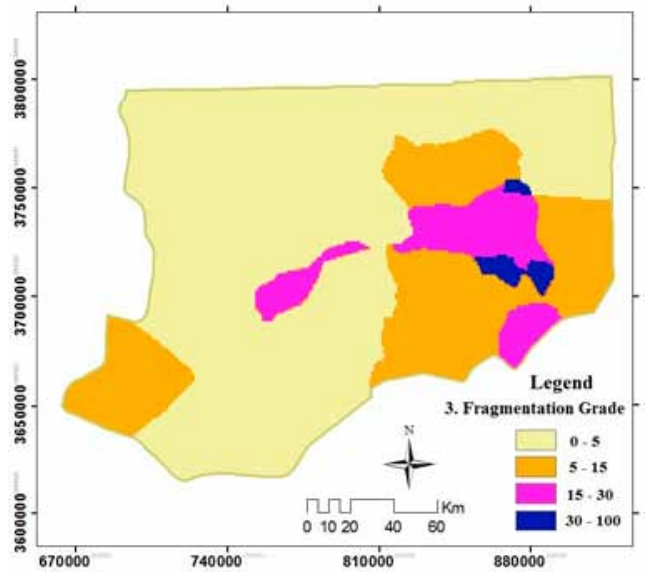

2)

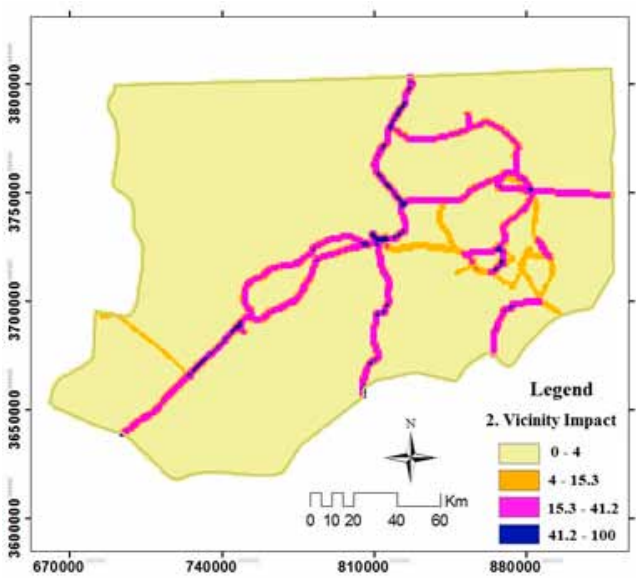

4)

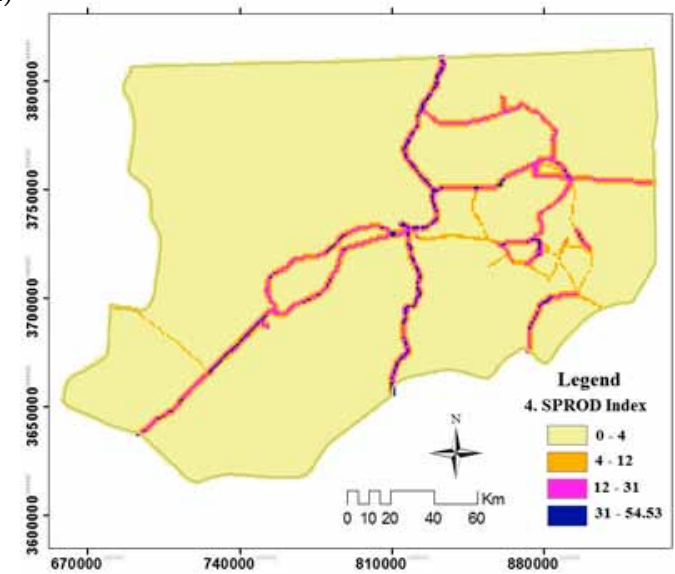

Fig. 2. 1) Traffic intensity $(T), 2)$ vicinity impact $(V), 3)$ fragmentation grade $(F)$ and 4$)$ the combination of the three sub-indices into the spatial road disturbance index (SPROADI); high values in red represent high road disturbance, low values in pale pink represent low road disturbance along the different sub-indices or the overall SPROADI outcome 
The value of SPROAD index, in the study which was done by Freudenberger et al. (2013) in Germany, ranged from 0 to 83.67 (Freudenberger et al. 2013). Comparison the two study areas, the levels of the road density is higher in Germany. The study area in eastern part of Isfahan is larger comparing the study area in Brandenburg State (38,000 $\mathrm{km}^{2}$ comparing $29,479 \mathrm{~km}^{2}$ in Germany), however in this study the volume of traffic in eastern part of Isfahan due to heavy vehicles is much higher in comparison with Germany.

Based on the SPROADI map, approximately 10 percent of the study area was affected by the road networks. The road networks in Naien and Khoor-o-Biabanak counties, caused habitat fragmentation and more accessibility to important conservation areas including Abassabad wild life refuge and Siahkouh national park, increasing the vulnerability of these two areas (Makki et al. 2013).

To assess the impacts of the roads network on the habitats of the Asiatic cheetah, we used the distribution map of the species across eastern part of Isfahan produced by Bordkhani (2013). Figure 3, shows the distribution map of suitable habitats for Asiatic cheetah. As the map indicates, the southern and south-eastern parts of the study area are suitable for Asiatic cheetah. The results revealed that 6 percent of the study area consists of the most suitable habitats. The Abassabad wild life refuge and Siahkouh national park are known as the most suitable areas for Asiatic cheetah in Isfahan Province. Important environmental features that are expected to influence the presence of cheetahs include vegetation cover, geographic features such as rocky outcrops, the presence of predators and the availability of water and prey were found in these areas (Bissett et al. 2007). Dense vegetation is believed to provide essential cover as refuge from predators, as well as camouflage when stalking prey. Cheetah's diet mainly consists of Jebeer gazelle, Goitered gazelle, wild sheep and wild goat. Water is important, not only for consumption, but as a feature around which prey species tend to congregate (Pettorelli et al. 2008).

The results of overlaying the SPROADI map with protected areas and suitable distribution ranges for the Asiatic cheetah in Eastern part of Isfahan province are shown in Figure 4. The roads network has intersected the suitable habitats of Asiatic cheetah in several parts, both inside and outside the protected areas. Southeastern part of the study area, which is the most suitable areas for Asiatic cheetah, has also been affected by the roads network. An important consequence of this human disturbance is habitat fragmentation which in turn has resulted in cheetah's population to form too small and isolated. Therefore, the Asiatic Cheetahs are more vulnerable to stochastic demographic events. The indirect effects on the species include changes or impacts that result from increased contact with humans and human land use

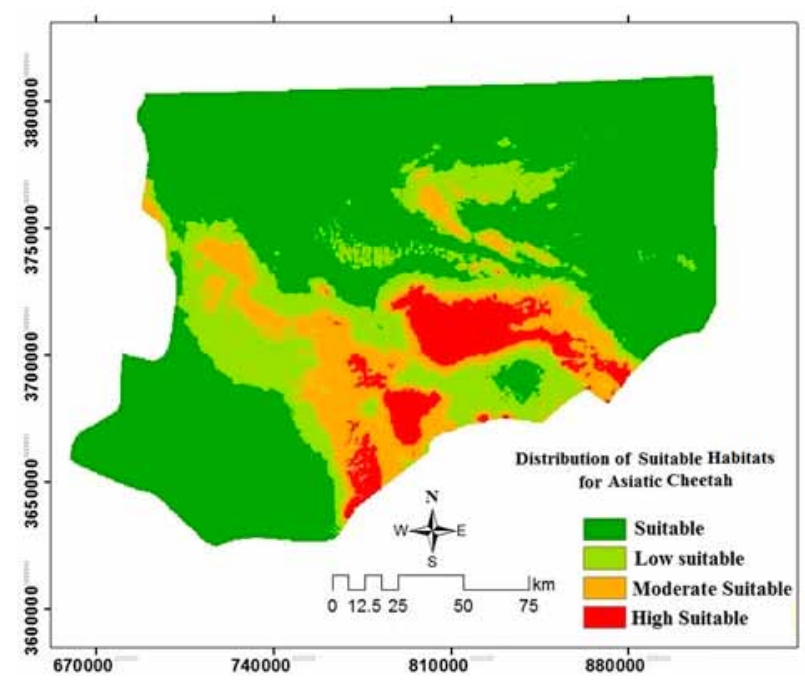

Fig. 3. Distribution and habitat suitability map of Asiatic cheetah at eastern part of Isfahan Province (Bordkhani 2013)

activities. Asiatic cheetah numbers are thought to be limited by the size of the prey populations on which they depend. The road networks increase the probability of prey's collision such as Jebeer gazelle and wild goat. Water is an important environmental variable, not only for consumption, but as a feature around which prey species tend to congregate. Crossing the roads by prey species to access water resources, located on the other side may increase the accidents (Carrillo et al. 2000). In addition, illegal hunting has a strongly influenced on the distribution and abundance of Asiatic cheetahs and prey species. Asiatic cheetahs and many prey species that normally use habitats on the edges of their distribution range may be subjected to increased vulnerability to illegal hunting on the habitat boundaries where human density is high (O'Brien et al. 2003).

Overlaying the protected areas and SPROADI maps revealed that the Abassabad wildlife refuge undergone the highest degree of roads network disturbances. This level of disturbance is mainly caused by the ArdakanChoopanan main road passed through the wildlife refuge which caused habitat fragmentation. There are two other main roads in the north and eastern part of Abassabad area. In addition to habitat fragmentation, high number of collisions happened on these road was also responsible for this level of disturbance. One of the reasons of high number of accidents in these roads is that, there are some springs in the other side of the road. Therefore, crossing the roads by wildlife species for accessibility to these water resources caused accidents (Field observation and personal communication with wildlife guards of Abassabad wild life refuge). There are some underpasses, but some species especially mammals did not use them because they escape from human constructions. In addition, these roads can have negative effects on these protected areas 
a)

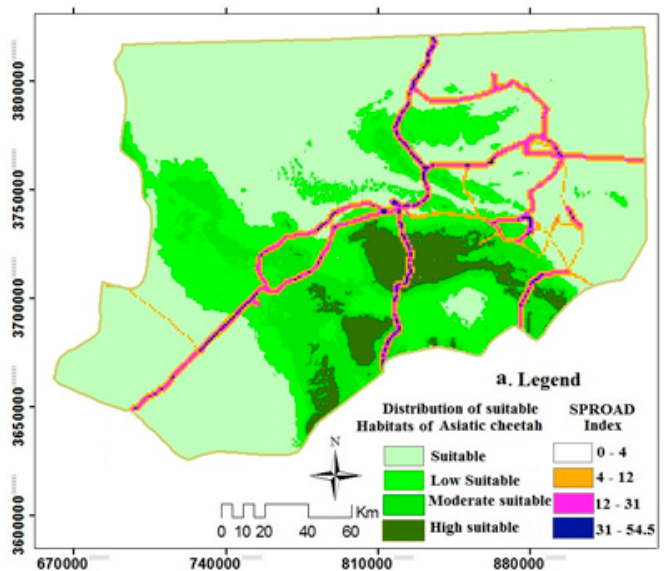

b)

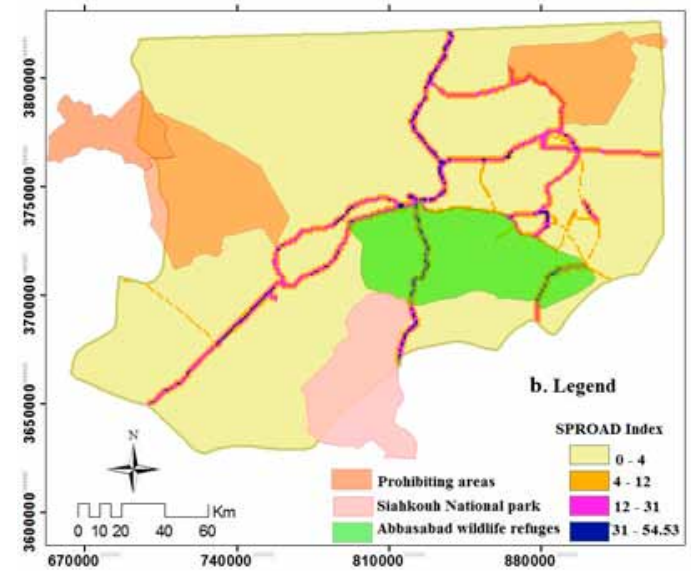

Fig. 4. Schematic representations of the spatial extent of overlaying SPROADI with a) most suitable habitats for the Asiatic cheetah and b) protected areas in study area impacted by the road networks

by increasing the hunter accessibility to these areas and decrease the security in these areas.

Table 2 shows the areas of protected areas, the areas of suitable habitats for Asiatic Cheetah fallen in to different protected areas and the levels of disturbances in different protected areas. Results of this study show that around 12 percent of Abassabad wild life refuge, including 77 percent suitable habitats for Asiatic cheetah, is affected by high level of road disturbances. Also, approximately 2 percent of Siahkouh national park, including 57 percent suitable habitats for Asiatic cheetah is affected by low level of road disturbances.

Table 2. The Area (ha) of Sensitive Habitats and the level of disturbance by roads (SPROADI)

\begin{tabular}{lcccc}
\hline \multirow{2}{*}{$\begin{array}{c}\text { Protected } \\
\text { areas }\end{array}$} & $\begin{array}{c}\text { Areas } \\
\text { (ha) }\end{array}$ & $\begin{array}{c}\text { Areas of } \\
\text { habitat } \\
\text { suitability of } \\
\text { Cheetah (ha) }\end{array}$ & \multicolumn{2}{c}{$\begin{array}{c}\text { Area of SPROADI } \\
\text { (ha) }\end{array}$} \\
\cline { 4 - 6 } $\begin{array}{l}\text { Abassabad } \\
\text { wild life } \\
\text { refuges }\end{array}$ & 305,433 & 233,973 & 14,800 & Low \\
\hline $\begin{array}{l}\text { Siahkouh } \\
\text { national park }\end{array}$ & 205,782 & 116,674 & - & 400 \\
\hline
\end{tabular}

\section{Conclusions}

The present study focused on the ecological impacts of roads network, which passes through Abassabad wildlife refuge and Siahkouh national park in the eastern part of Isfahan province. The key affected species, Asiatic Cheetah (Acinonyx jubatus venaticus) classified as Critically Endangered (CR) on the IUCN Red List was subject to impact analyses.

We used Spatial Road Disturbance Index (SPROADI), as a new landscape index for the ecological impact assessment of the roads network. This index uses three sub-indices including traffic intensity, vicinity impact and fragmentation grade to calculate the ecological impacts of road networks.

Results obtained through quantifying the landscape Index (SPROADI) showed that the degree of disturbance by roads network is between 0 and 54.53. Our results also revealed that 12 percent of Abassabad wildlife and wide range of suitable habitats for Asiatic Cheetah were affected by roads, which presents a conservation concern for this critically endangered species. Our results demonstrate that the roads network not only reduced the area of the original habitat in the refuge but also in addition to the physical occupation of land use and maintenance of the road caused disturbance and thus further reduced the quality of the remaining habitat.

Our study demonstrated that SPROADI method might provide a powerful tool for assessing ecological impact of transportation infrastructures on populations of far-ranging species of conservation concern and for incorporating this index into systematic conservation planning.

\section{Acknowledgements}

We express our appreciation to Department of the Environment of Iran (DOE). We are grateful to guards of $\mathrm{Ab}$ basabad wildlife refuge, local people, Dr Mahmoud reza Hemami, Dr Hossein Madadi and Dr Hossein Moradi, for their valuable inputs and cooperation to this study.

\section{References}

Akbari, H.; Jalalpour, M.; Hojati, V.; Gol Mohamadi, M. 2011. Identification of reptiles and birds fauna of Abassabad wildlife refuge, Journal of Animal Biology 3(2): 1-12.

Balkenhol, N.; Waits, L. P. 2009. Molecular road ecology: exploring the potential of genetics for investigating transportation impacts on wildlife, Molecular Ecology 18(20): 4151-4164. https://doi.org/10.1111/j.1365-294X.2009.04322.x 
Benítez-López, A.; Alkemade, R.; Verweij, P. A. 2010. The impacts of roads and other infrastructure on mammal and bird populations: a meta-analysis, Biological Conservation 143(6): 1307-1316. https://doi.org/10.1016/j.biocon.2010.02.009

Bissett, C.; Bernard, R. T. F. 2007. Habitat selection and feeding ecology of the cheetah in thicket vegetation: is the cheetah a savannah specialist?, Journal of Zoology 271(3): 310-317.

Bordkhani, M. 2013. Distribution modelling of Asiatic Cheetah (Acinonyx jubatus venaticus): Master's thesis. Isfahan University of Technology.

Carrillo, E.; Wong, G.; Cuarón, A. D. 2000. Monitoring mammal populations in Costa Rican protected areas under different hunting restrictions, Conservation Biology 14(6): 1580-1591. https://doi.org/10.1046/j.1523-1739.2000.99103.x

Eigenbrod, F.; Hecnar, S. J.; Fahrig, L. 2009. Quantifying the road effect zone: threshold effects of a motorway on anuran populations in Ontario, Ecology \& Society 14(1): 24. https://doi.org/10.5751/ES-02691-140124

Epps, C. W.; Palsbøll, P. J.; Wehausen, J. D.; Roderick, G. K.; Ramey, R. R.; McCullough, D. R. 2005. Highways block gene flow and cause a rapid decline in genetic diversity of desert bighorn sheep, Ecology letters 8(10): 1029-1038. https://doi.org/10.1111/j.1461-0248.2005.00804.x

Ewers, R. M.; Didham, R. K. 2007. The effect of fragment shape and specie's sensitivity to habitat edges on animal population size, Conservation Biology 21(4): 926-936. https://doi.org/10.1111/j.1523-1739.2007.00720.x

Forman, R. T. T.; Sperling, D.; Bissonette, J. A.; Clevenger, A. P.; Cutshall, C. D.; Dale, V. H.; Fahrig, L.; France, R. L.; Goldman, Ch. R.; Heanue, K.; Jones, J.; Swanson, F.; Turrentine, Th.; Winter, Th. C. 2003. Road Ecology: Science and Solutions. Washington, DC: Island Press. 504 p.

Freudenberger, L. R.; Hobson, P.; Rupic, S.; Pe’er, G.; Schluck, M.; Sauermann, J.; Kreft, S.; Selva, N.; L. Ibisch, P. 2013. Spatial road disturbance index (SPROADI) for conservation planning: a novel landscape index, demonstrated for the State of Brandenburg, Germany, Landscape Ecology 28(7): 13531369. https://doi.org/10.1007/s10980-013-9887-8

Goodwin, B. J.; Fahrig, L. 2002. Effect of landscape structure on the movement behaviour of a specialized goldenrod beetle, Trirhabda borealis, Canadian Journal of Zoology 80(1): 2435. https://doi.org/10.1139/z01-196

Hoskin, C. J.; Goosem, M. W. 2010. Road impacts on abundance, call traits, and body size of rainforest frogs in northeast Australia, Ecology \& Society 15(3): 15.

Jaeger, J. A. G. 2000. Landscape division, splitting index, and effective mesh size: new measures of landscape fragmentation, Landscape Ecology 15(2): 115-130. https://doi.org/10.1023/A:1008129329289

Jump, A. S.; Peñuelas, J. 2005. Running to stand still: adaptation and the response of plants to rapid climate change, Ecology Letters 8(9): 1010-1020. https://doi.org/10.1111/j.1461-0248.2005.00796.x

Keller, I.; Nentwig, W.; Largiader, C. R. 2004. Recent habitat fragmentation due to roads can lead to significant genetic differentiation in an abundant flightless ground beetle, Molecular Ecology 13(10): 2983-2994.

https://doi.org/10.1111/j.1365-294X.2004.02310.x

Laurance, S. G. W.; Stouffer, P. C. 2004. Effects of road clearings on movement patterns of understory rainforest birds in central Amazonia, Conservation Biology 18(4): 1099-1109. https://doi.org/10.1111/j.1523-1739.2004.00268.x
Lin, S. C. 2015. The width of edge effects of road construction on fauna and ecologically critical road density, Journal of Environmental Engineering and Landscape Management 23(4): 241-250. https://doi.org/10.3846/16486897.2015.1054290

Madadi, H.; Moradi, H.; Fakheran, S.; Jokar, M.; Makki, T. 2014. Modelling of emission of the sound pollution of Isfahan's west freeway in the Ghamishloo wild life refuge using the SpreAD-GIS, Iranian Journal of Applied Ecology 3(9): 43-55.

Makki, T.; Fakheran, S.; Moradi, H.; Iravani, M.; Senn, J. 2013. Landscape-scale impacts of transportation infrastructure on spatial dynamics of two vulnerable ungulate species in Ghamishloo Wildlife Refuge, Iran, Ecological Indicators 31: 6-14. https://doi.org/10.1016/j.ecolind.2013.03.001

Martín-Cejas, R. R. 2015. The environmental impact caused by road access to Timanfaya Natural Park on Lanzarote Island, Transportation Research Part D: Transport and Environment 41: 457-466. https://doi.org/10.1016/j.trd.2015.09.027

O’Brien, T. G.; Kinnaird, M. F.; Wibisono, H. T. 2003. Crouching tigers, hidden prey: Sumatran tiger and prey populations in a tropical forest landscape, Animal Conservation 6(2): 131-139. https://doi.org/10.1017/S1367943003003172

Opdam, P.; Verboom, J.; Pouwels, R. 2003. Landscape cohesion: an index for the conservation potential of landscapes for biodiversity, Landscape Ecology 18: 113-126. https://doi.org/10.1023/A:1024429715253

Parris, K. M.; Schneider, A. 2009. Impacts of traffic noise and traffic volume on birds of roadside habitats, Ecology \& Society 14(1): 29. https://doi.org/10.5751/ES-02761-140129

Pascual-Hortal, L.; Saura, S. 2006. Comparison and development of new graph-based landscape connectivity indices: towards the prioritization of habitat patches and corridors for conservation, Landscape Ecology 21: 959-967. https://doi.org/10.1007/s10980-006-0013-Z

Pettorelli, N.; Hilborn, A.; Broekhuis, F.; Durant, S. M. 2008. Exploring habitat use by cheetahs using ecological niche factor analysis, Journal of Zoology 277(2): 141-148. https://doi.org/10.1111/j.1469-7998.2008.00522.x

Rico, A.; Kindelmann, P.; Sedlacek, F. 2007. Barrier effects of roads on movements of small mammals, Folia Zoology 56(1): 1 .

Riley, S. P. D.; Pollinger, J. P.; Sauvajot, R. M.; York, E. C.; Bromley, C.; Fuller, T. K.; Wayne, R. K. 2006. A southern California freeway is a physical and social barrier to gene flow in carnivores, Molecular Ecology 15(7): 1733-1741. https://doi.org/10.1111/j.1365-294X.2006.02907.x

Selva, N.; Kreft, S.; Kati, V.; Schluck, M.; Jonsson, B.; Mihok, B.; Okarma, H.; Ibisch, P. L. 2011. Road less and low-traffic areas as conservation targets in Europe, Environmental Management 48(5): 865-877. https://doi.org/10.1007/s00267-011-9751-Z

Trombulak, S. C.; Frissell, C. A. 2000. Review of ecological effects of roads on terrestrial and aquatic communities, Conservation Biology 14(1): 18-30. https://doi.org/10.1046/j.1523-1739.2000.99084.x

UNEP. 2001. Globio: global methodology for mapping human impacts on the biosphere. UNEP/DEWA/TR.01-3. Environment Information and Assessment Technical Report. UNEP. Nairobi, UNEP: 55 .

Van Langevelde, F.; Van Dooremalen, C.; Jaarsma, C. F. 2009. Traffic mortality and the role of minor roads, Journal of Environmental Management 90(1): 660-667. https://doi.org/10.1016/j.jenvman.2007.09.003 
Shekoufeh NEMATOLLAHI. PhD Student of Environmental Sciences, Department of Natural Resources, Isfahan University of Technology. She obtained MSc and BSc in Environmental Sciences, Isfahan University of Technology. Her research interests include: Ecological Impacts of Transportation Infrastructure, Spatial analysis, Landscape Pattern Changes, Land use Planning. She has published more than 10 refereed and conference papers.

Sima FAKHERAN. Assistant Professor of Environmental Sciences, Department of Natural Resources, Isfahan University of Technology. President of Iranian Regional Chapter of International Association for Landscape Ecology (IALE-Iran). She got PhD in Environmental Sciences, Institute of Evolutionary Biology and Environmental Studies (IEU), University of Zurich, Switzerland. MSc of Environmental Science, Faculty of Natural Resources, University of Tehran, Iran, and BSc of Environmental science, from Faculty of Natural Resources, Isfahan University of Technology, Iran. Her research interests include: Landscape Ecology, Conservation Planning, Wildlife corridor design, Ecological Impacts of Climate Change. She has published more than 30 refereed scientific papers.

Alireza SOFFIANIAN. Associate Professor of Environmental Sciences, and Dean of Department of Natural Resources, Isfahan University of Technology. He got PhD of Geography (GIS), from Sorbonne University, Master of Environmental science, from University of Tehran, Iran, and BSc of Fisheries and Environmental Science, University of Tehran, Iran. His research interests: Spatial analysis, Land use Planning, Change detection. He has published more than 40 refereed scientific papers. 